\title{
Breaking Ground: Architecture, Art, and Performance as a Tool of Engaged Design
}

\section{MO ZELL}

University of Wisconsin-

Milwaukee \& bauenstudio

\author{
JOELLE WORM \\ University of Wisconsin- \\ Milwaukee
}

\author{
EMILIA LAYDEN \\ Haggerty Museum of Art
}

\author{
MARC ROEHRLE \\ University of Wisconsin- \\ Milwaukee \& bauenstudio
}

Breaking Ground, a temporary installation situated on an urban campus, brought together a museum, an architectural installation, and a dance performance to initiate a reexamination of the relationships between space, place, and activity. The modest sculpture garden at Marquette University's Haggerty Museum of Art served as the site for the installation. Commissioned for a group show titled 'Current Tendencies IV: Topography Transformed,' the architects created a temporary installation that traced the pathways through the garden then elevated the users above the ground plane to reconsider an existing context while testing the phenomenological qualities of building materials and tectonics. Changes in elevation and layers of intimacy enhanced by the changing transparency of the polycarbonate provided a dynamic stage for an improvisational dance piece. Blurring their respective roles, dancers, musicians, and audience members interacted with one another and with Breaking Ground by engaging the pathways and landscape of the sculpture garden. The purposeful siting of the installation disrupted a number of existing experiences for the museum, patrons/audience, and the performers; eliciting a conversation regarding the roles of the arts, institutions and experience within the public realm.

\section{INSTITUTIONAL CRITIQUES}

Installations as a form of architecture offer not only an opportunity to critique but also to reconsider the boundaries of the discipline. Bernard Tschumi in The Manhattan Transcripts states that "Architecture is not simply about space and form, but also about event, action, and what happens in space." ${ }^{1}$ Tschumi amplifies a direction for architecture that elevates the relationship between space and use. At about the same time Tschumi was emphasizing experience as a foundational condition of architecture, other institutions and forms of art were reinventing their own relationships to their disciplinary context. In the mid to late 20th century, museums were democratizing their missions through the additions of outreach and education programming; moving the collection outside the museum walls into a space of public interface and consumption. Simultaneously, dance not only moved outside the theater into the public realm, but began to question the traditional roles of the performers, the audience, and their relationship. In all three disciplines there was a shift from a focus on time and space (the universal) to one about place and event (the archetypal). This paper questions the relationships between installations, museums, and performance through site specific experiences in a public space related to the installation Breaking Ground.

\section{ARCHITECTURE [INSTALLATION] AS EXPERIENCE}

In Installations by Architects, Sarah Bonnemaison and Ronit Eisenbach offer that architects deploy installations in three categories: "to experiment with both material and social dimensions of architecture, to create conversations both with academics and the general public about the built environment, and to educate future architects."2 Fundamentally, installations provide architects a direct relationship to an audience because their design parameters are strategically limited. As Mark Robbins states: "an installation is a distillation of the experiences of architecture." ${ }^{3}$ Bonnemaison and Eisenbach further state that "(a)n installation('s) function turns away from utility in favor of criticism and reflection; and it foregrounds the content. [Installations] also offer precious freedom to experiment." Implicit in this observation is an understanding that installations require a different set of construction parameters than typical design/build projects; that they require a critical stance, one that provides opportunities to not only solve problems, but also to proffer questions.

This idea that architecture is an arrangement of experiences negotiated through materials and space is revisited in "Between Dance and Architecture" Authors Rachel and Alice Sara question the definition of architecture as a static construction to a notion of the experiences of the place or its "use." "Use" they say "constructs the function, atmosphere and meaning of a place. When you change the function, atmosphere and meaning of a place then you construct architecture." ${ }^{5}$ Architecture, therefore, becomes not only the physical and built environment, but also the experiential aspects of inhabiting a place. This "shift in focus from the building (object) to the person (subject), from the (hard) walls to the (sentient) body and perhaps even from the designer to the user" opens up the possibilities for "collaboration [that] is itself a form of resistance to disciplinary boundaries, in the way that it interrupts the binary categorizations of each." ${ }^{6}$ Such expanded notions of what constitute architecture encourage dialogue and interaction across disciplines with potentially exciting new results. 


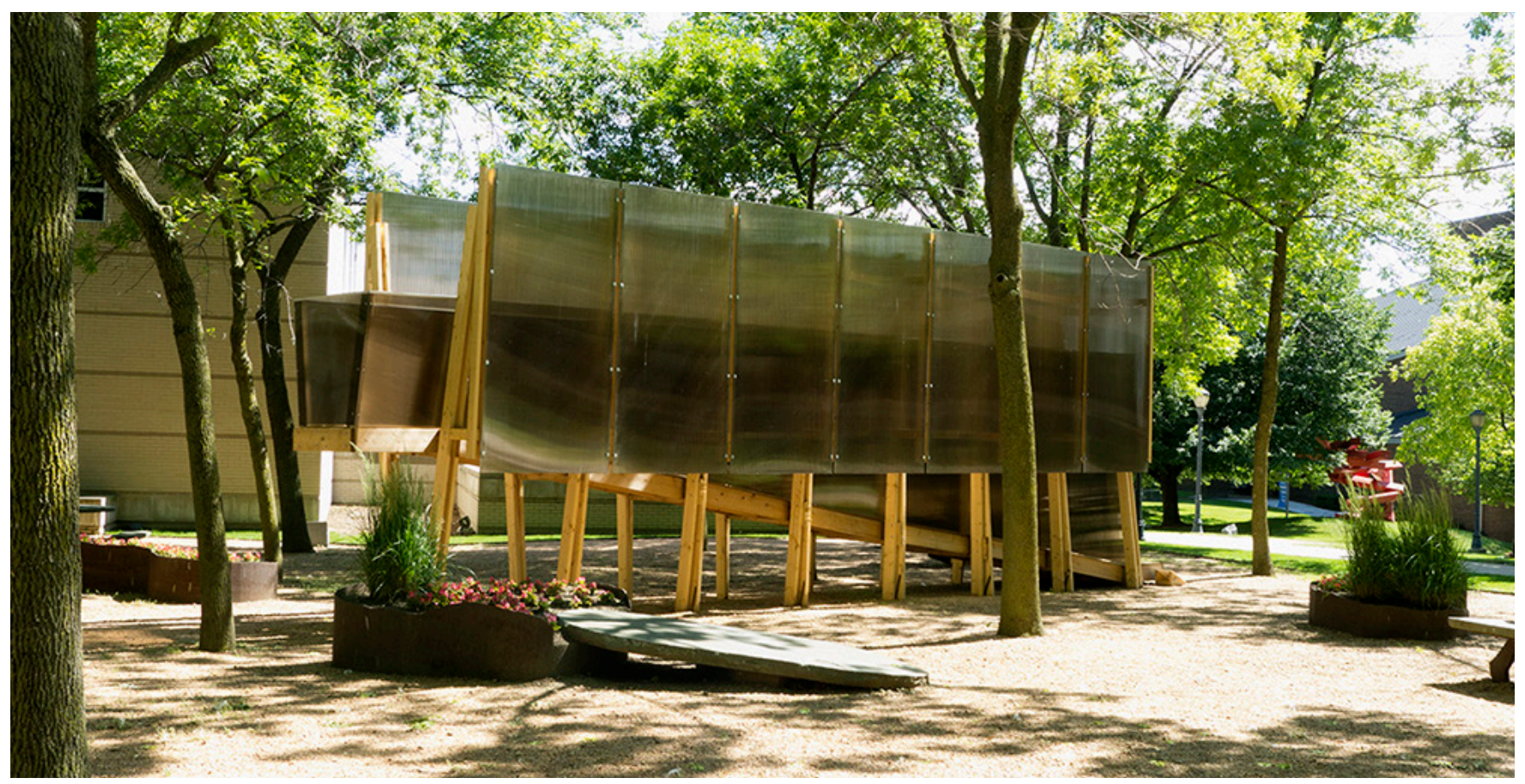

Figure 1: Breaking Ground cuts across the bosque of trees at the Haggerty Museum of Art Sculpture Garden.

\section{SHIFTING ATTITUDES IN MUSEUM OUTREACH}

In Andrew McClellan's edited volume Art and Its Publics: Museum Studies at the Millennium, he writes about the "tensions within art museums that compromise their ability to fully extend themselves to the public."7 He identifies the private interests that result from museums' "descent from private collections" and the desires "to evolve towards an ideal of full integration with the public sphere." 8 This shift in philosophy was one from a focus on the collection to the potential role the collection could play in society. Benjamin Ives Gilman, curator of the Boston Museum of Fine Arts from 1893-1925 espoused a new philosophy on the roles of museums: "'The problem of the present is the democratization of museums: how they may help to give all men a share in the life of the imagination'."'

Whether related to this new philosophy on the role of museums in civic life, or in response to declining museum attendance recorded in Great Britain and the United States in the $1940 \mathrm{~s},{ }^{10}$ museums "witnessed an extraordinary expansion of educational activity..., much of it dealing with issues of social relevance and cultural history." ${ }^{11}$ Furthering this trend in museum outreach was the political and social unrest of the 1960s. "[T] he world beyond the museum had changed dramatically and many museums, especially ones in urban settings, awoke to find themselves out of touch with social developments." 12

High among the demands made of the profession was the "democratization," or engagement, of museums, all the more imperative given the federal subsidies they received.
Nancy Hanks, Chair of the National Endowment for the Arts, concluded: "I do not think we can any longer spend time discussing the role of the museum as a repository of treasures versus its public role. It simply has to be both."13

As an academic art museum at a private, Jesuit university, The Haggerty Museum of Art attempts to meet the needs of many constituents. In addition to supporting the educational mission of its parent organization committed to the pursuit of social justice, and creating opportunities to enhance the academic curriculum, the museum also strives to connect the academy to the public. Students, faculty and staff are the primary audience, but members of the general public also benefit from unlimited (free admission, open daily) access to the museum's exhibitions and programs.

The mandate to connect "town to gown" is easy to grasp as a concept, but its translation to practice proves to be more difficult . The design of relative, inclusive, and culturally responsive programming is a starting point, but the existing strata of institutional barriers - a museum ensconced in the urban campus of a private university for example - limits opportunities for true engagement. How does a member of the general public navigate these spatial politics, when merely setting foot on the campus can feel like trespassing?

Architectural interventions and/or art installations are often deployed to transform these kinds of interstitial public spaces - between city and campus, campus and museum, in this case - into more welcoming gateways. As documented in McClellan's Art and Its Publics: Museum Studies at the Millennium, Harriet F. Senie spent a semester with graduate students from The City College and The City University of New York who "observed, eavesdropped and engaged the 


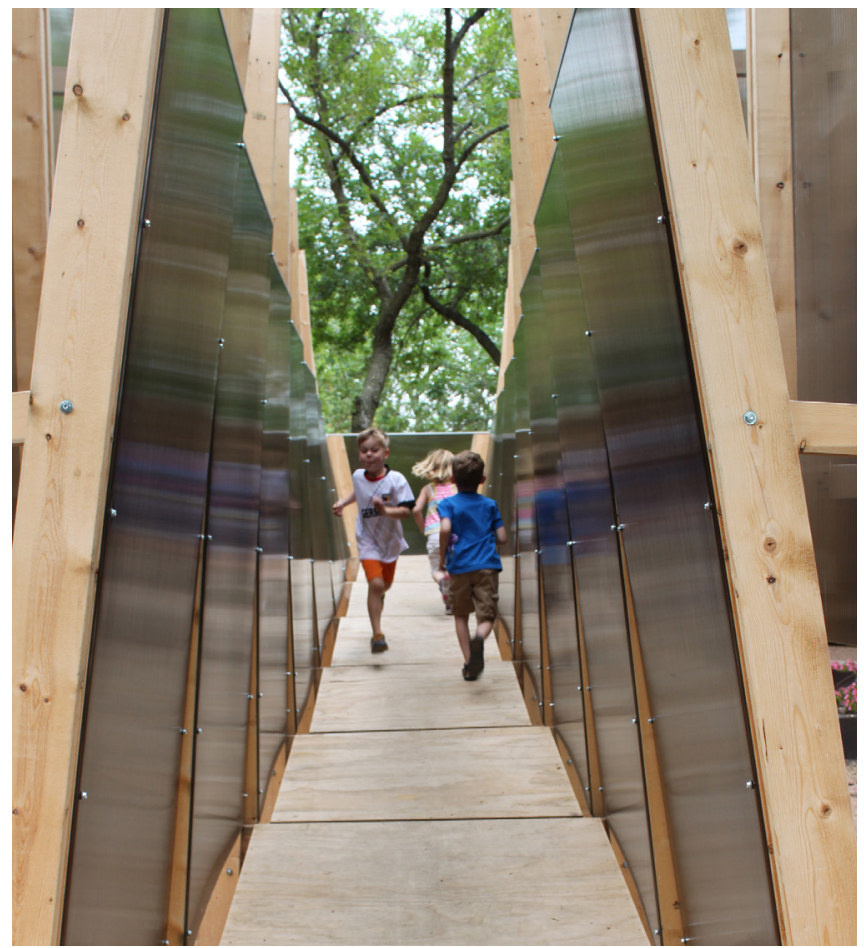

Figure 2: Not only does the scale of the space change when children run along the ramp but the function of Breaking Ground transforms into, what Harriet Senie would call a humanizing element, a playground.

audience for a specific work of public art."14 Senie's findings included that " $[t]$ he general condition of the site directly affects perception of the art" as well as "what people generally do there."15 For example, people's interpretation of a work of art was affected by the cleanliness of the location as well as the characters inhabiting the space. Many of the parks with public art that were part of the study included populations of homeless people, which tended to affect interpretation towards the negative or gloomy. ${ }^{16}$ Conversely, the functions of an area affected how audiences interacted with works. "Although some people were initially hesitant to talk about public art, they had no problem using it according to their needs or wants as a photo op, street or playground furniture (depending on age)." ${ }^{\prime 17}$

Senie continued to conclude that "[a]udience use of public art highlights what people find missing in our urban environment: places to sit and/or play, humanizing elements in general, place markers, and a sense of civic identity." ${ }^{18}$ The variations in use for public art included using art as a meeting place or a geographic marker, as a place to hang notices, and even use of the work as a civic logo. ${ }^{19}$ Finally, Senie found that "[i]nteractivity of any kind seems to prompt a positive audience response." ${ }^{20}$ If an audience could have some kind of bodily/kinesthetic experience with the work, it usually invoked a fond response as well as created a memory of the piece.

\section{DANCE AS ENGAGEMENT}

Though American Modern Dance of the 1930s and 1940s had moved away from the canon of the European ballet, "dance companies, whether they were classical, modern, or postmodern, had practiced the same disciplinary techniques and reinforced the same hierarchical power relations as in society generally."21 Judson Church performers of the 1960s, on the other hand, began to move dance out of hierarchical power relations both within company structures and in shifting the conversation regarding what was possible between performers and their audience. In Dancing Democracy, Ann Daly quotes Judson dancer Twyla Tharp who says "I see dance...as glue for a community. Dance should not just divide people into audience and performers. Everyone should be a participant, whether going to classes, or attending special events or rehearsals." ${ }^{22}$ Similar to the changes happening relative to public access of the museum and moving content beyond the limits of the museum architecture, Judson dancers moved performance out of theaters, using vacated churches (Judson itself was a church in New York City's Greenwich Village), lofts and studios, and outdoor public parks, squares and busy street corners. The liberation of dance from the confines of the stage increased the interactive possibilities described by Tharp. In discussing the potential power of site-specific choreography, Erinn Kelley Thompson Ernst describes "the connection between the dancers and the audience is heightened when the performance is site-specific because there are no clearly demarcated barriers or positions identified as more advantageous than any alternate perspective." ${ }^{23}$

In addition to freeing dance from the theater space, Judson performers utilized improvisational practices to "return decision making authority to the dancer." ${ }^{24}$ Modern dancers of the 1930s-1950s were still made to mold their bodies into the shape of their principal choreographer so that even if the movements weren't as highly codified as in the ballet, it certainly did not prioritize individual exploration over the unison of the ensemble. The Judson dancers, on the other hand, cultivated a "freedom to follow one's Intuitions and Impulses in improvisation." 25

The alternative spaces in which Judson dances took place created a new kind of performer-audience empathy challenging to achieve in the darkened theater with seats set at a distance from the action of the stage. Faith $\mathrm{H}$. Morrison articulates that "site-specific dance fulfills a human desire for interaction between people, performance, and place...blurs the boundaries between performers and the audience," ${ }^{26}$ which harkens back to Tschumi's redefinition of architecture to include event, action and what happens in space and has the potential to elevate the role of the architecture to one of engaged protagonist in such performances. The gap closed by the disruption of the theater context allows for a greater likelihood that audiences will "feel kinesthetic empathy with the performers" and in turn engage in an "arts based civic dialogue"27 that in and of itself becomes a sort of institutional critique. 


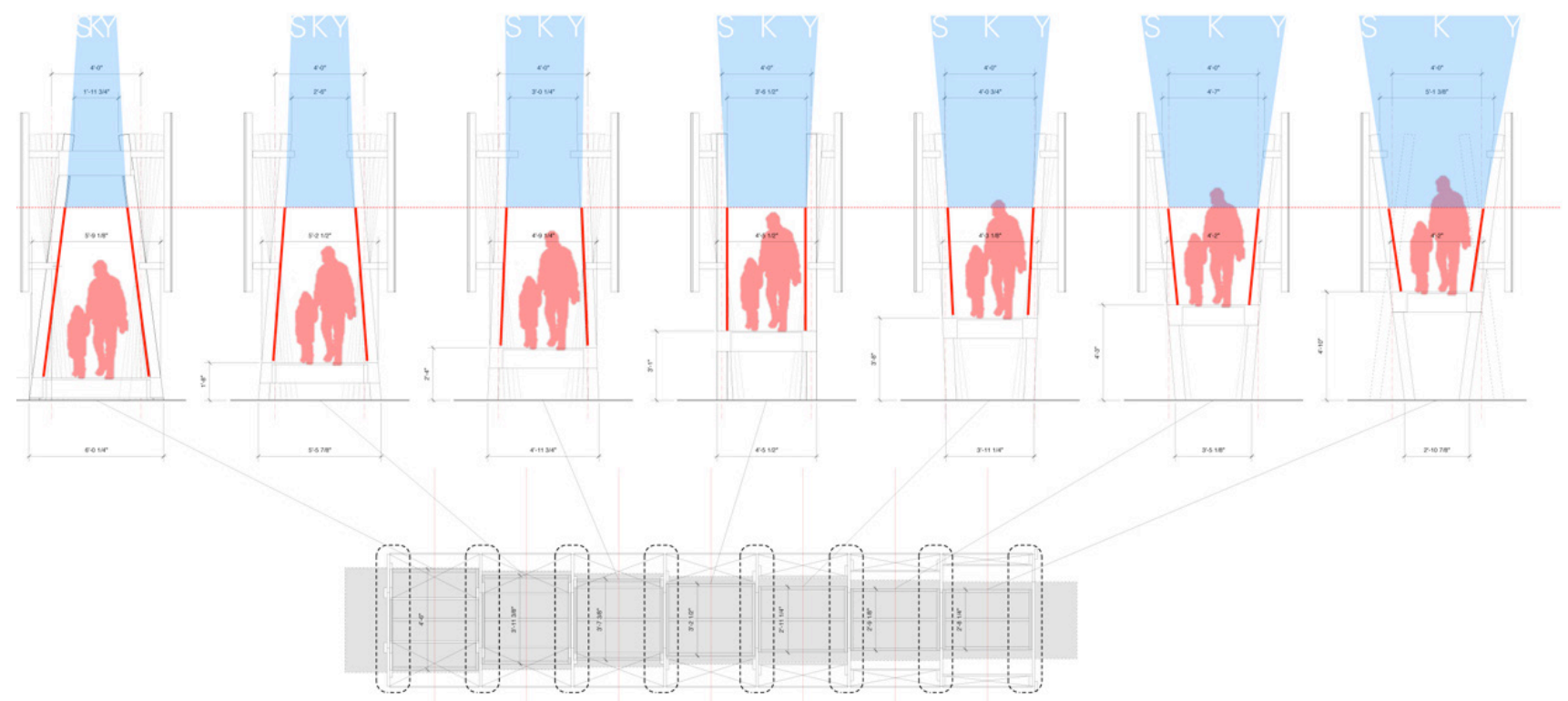

Figure 3: Illustration of $2 x$ lumber and polycarbonate panels framing the space occupied by the body. The space defined by the polycarbonate panels fluctuates as it reaches to the tree canopy above and sky beyond.

\section{THE MUSEUM: CONNECTING EXPERIENCES ACROSS TIME}

In 1983, then-emerging artist Keith Haring was invited to paint a mural on the construction fence built in preparation for the ground-breaking of Marquette University's Haggerty Museum. In this collaborative endeavor, 24 4x8 plywood panels were laid out to create an $8^{\prime}$ high by $96^{\prime}$ long canvas. This act of creating art outside of the museum coincided with the general trend towards the democratization of museums mentioned above.

Haring spent three days in Milwaukee-under the eyes of a very engaged public-painting both sides of the construction fence, sometimes with the help of Marquette University students. One side of the fence features a lively and crowded composition of dancing and twisting figures or animal-figure hybrids, with MARQUETTE emblazoned on one end and a large three-eyed, smiling face on the other. The reverse side of the fence repeats two of Haring's trademark characters: the "Barking Dog" and the "Radiant Baby."

Keith Haring's interest in semiotics and his admiration for graffiti art influenced the development of his signature pictographic style. For Haring, art was a tool for communication with a wide audience and as a call to social justice.. In fact, he accepted the Haggerty founding director's invitation to paint the fence at the construction site because of its highly visible location near a major highway interchange. Haring hoped that Construction Fence would "provide enjoyment, provoke discussion, and energize people."28
The Haggerty's commission of Haring's street art/graffitistyle work, also raised questions about the kind of art you might find in a museum. Untrained in a classical sense, the recognition of Haring (and other street/graffiti artists of the 80 s such as Jean-Michel Basquiat) opened museums to new considerations of what was deemed "high art." Under these terms, the traditional hierarchy between what was considered art (plywood and external house paint) and what the container was for it (the museum) were inverted. The completed work was intended as a temporary installation that would be dismantled and discarded once the museum was built, but the museum's director went on to accession it into the permanent collection, making it now one of the most iconic works in the museum's collection.

With Breaking Ground, the Haggerty once again posed a question about what constituted art and where it should be. Not simply a sculpture placed just outside the museum's doors, Breaking Ground suggested a trajectory through which to explore the sculpture garden and invited patrons to enter and engage this building/non-building [inside/outside] installation, implying the Haggerty's liberal idea of what constitutes art.

The museum also organized opening and closing receptions for Breaking Ground, which were free and open to the public. The opening focused on the installation itself and the closing featured the dance and music performance described below. Both events encouraged an engaged approach to art consumption. Held outside of the museum's walls, it was possible for any passerby to become a participant in the experience. Coupled with the exhibition of the 1983 Haring pieces inside the museum, the reception events made it possible for audiences to encounter the art historical context for Breaking Ground while simultaneously experiencing the piece itself. 


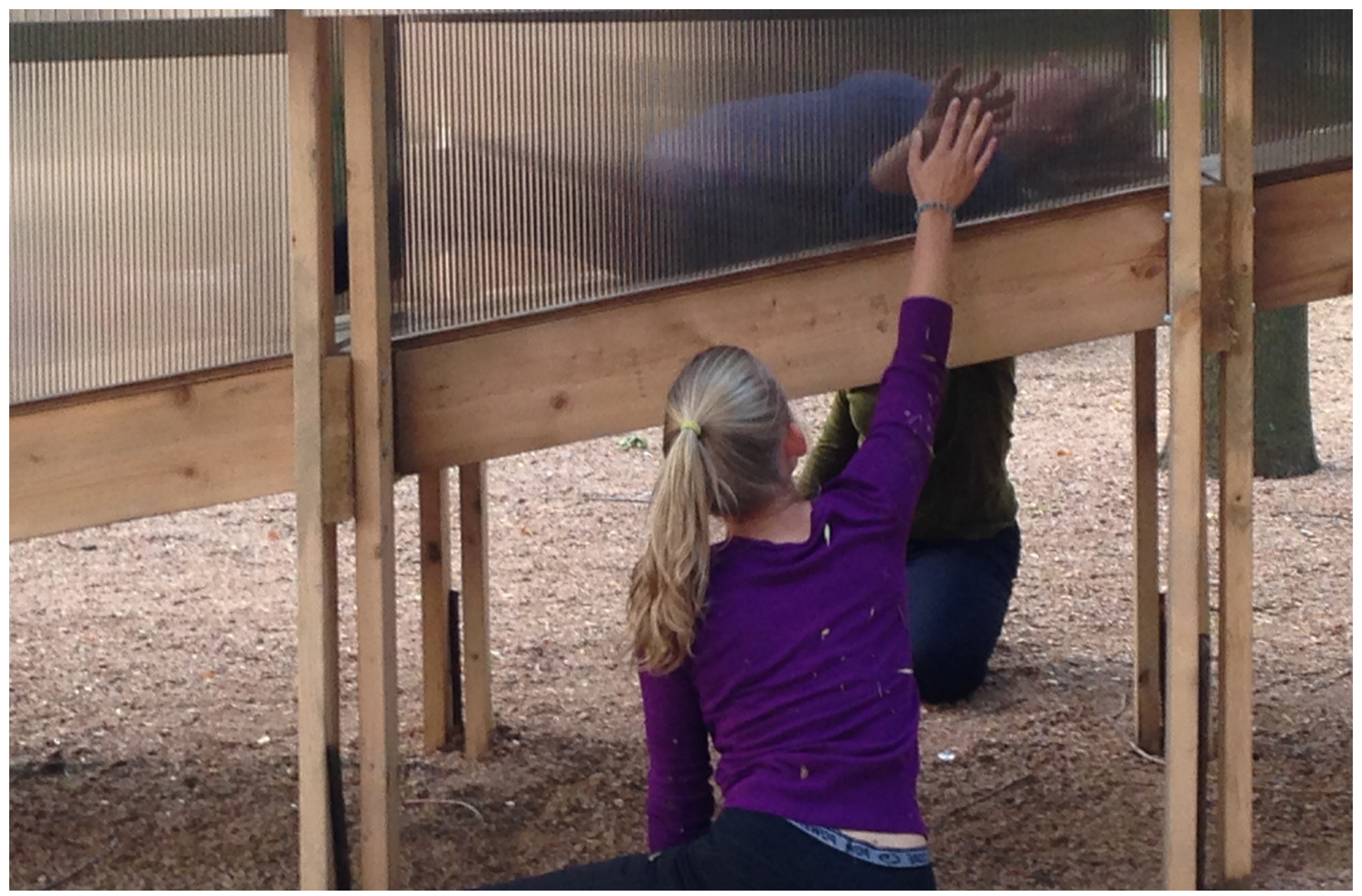

Figure 4: Dancers connect three spaces of the installation at a point of shift in the translucent polycarbonate panels.

In its collaboration with an architectural practice (and then dancers and musicians), the museum expanded its patronage to individuals who may have not shown up for the reception without this linkage to their professional or recreational interests.

In commissioning an architectural installation, and further activating it with an improvisational dance performance, the Haggerty Museum looked beyond traditional disciplinary and spatial boundaries. Instead of defining community engagement as a series of outreach programs, the Haggerty, through projects such as this, promoted relational, discursive art practices that invited collaboration with individuals, communities and institutions.

\section{INSTALLATION: CHANGING PUBLIC SPACE}

The architects for Breaking Ground transformed readily assembled materials like $2 x$ lumber, plywood and polycarbonate panels into a new type of site-specific aperture. The installation created various user experiences that responded to the site: controlled views, dynamic space (occupying an elevated ground plane inside an active space, standing within the tree canopy, within the space of the sculpture garden, surrounded by the museum and other academic buildings), and voyeuristic (being viewed, viewing the sky, the city, and viewing others). As Bonnemaison and Eisenbach stated, for installations, experience is the currency - with no assigned programming - the influences of human agency change the unprogrammed to one that empowers the individual with control of public space. That shift in focus, as might be deemed a post-critical turn, from object to person, mentioned by Sara and Sara, meant that the architectural function was the user engagement.

Breaking Ground expanded the territory of site-specificity through controlled views aligned toward significant urban landmarks including the Calvary Presbyterian Church and Ernest Shaw's sculpture Ruins X - drawing conclusions about their physical proximity and cultural relevance. By creating an elevated position in the sculpture garden, Breaking Ground changed the perceived relationship of the user to church - changing the power structures that regulate the built environment. The user moved into a place of prominence onto a dais much like the speaker's podium from El Lissitzky's 1920 Lenin Tribune Tower project. This pulpit disrupted the traditional campus hierarchies by providing a space for an individual voice on a private campus at the edge of a distressed urban neighborhood.

Breaking Ground occupied a stretch a land within a bosque of trees spaced 20' apart and adjacent to a series of blank walls 


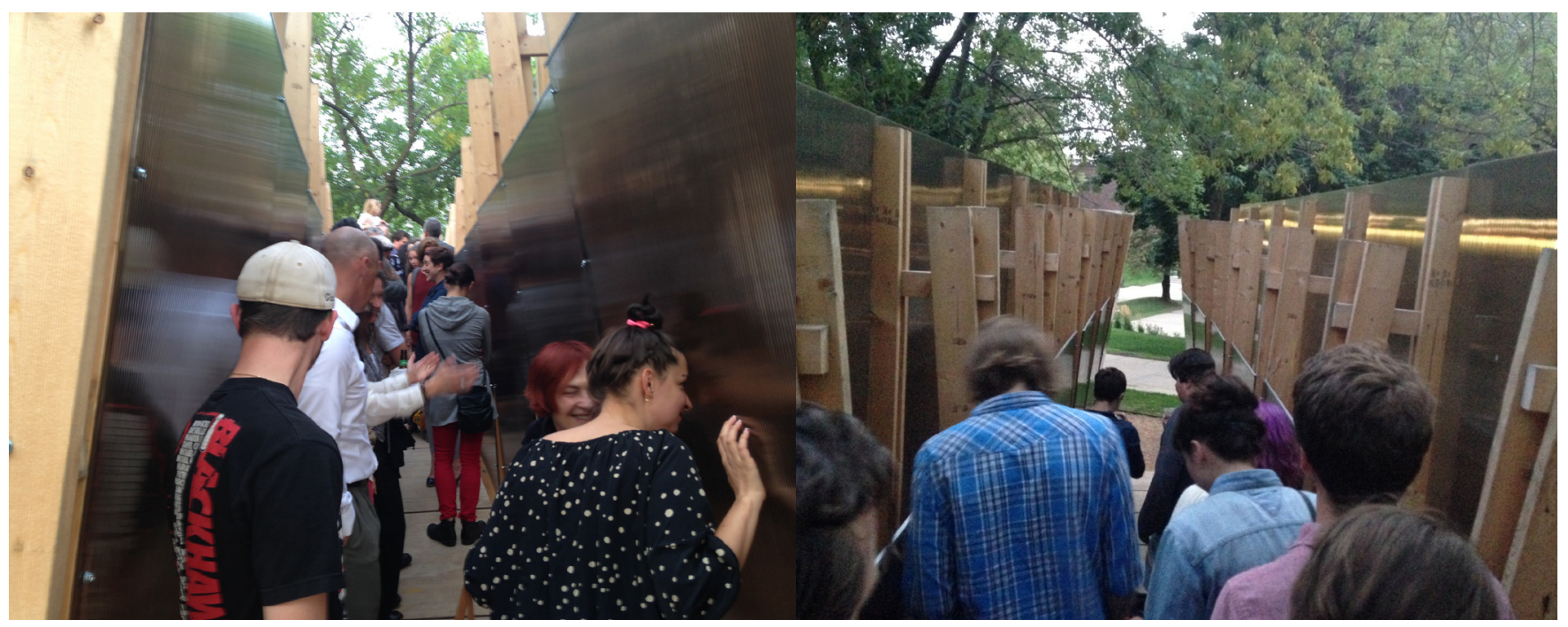

Figure 4: Inside Breaking Ground the audience occupies the position previously held by the performers.

from adjacent buildings including the museum. The space, identified as the museum's sculpture garden, performed mostly as a passageway

museum's sculpture garden, performed mostly as a passageway through campus. Several Ernest Shaw-designed tables, planters and benches, hewn from blue granite and iron, and rendered in biomorphic shapes, are installed in the space. Commissioned in 1985, these organic forms were meant to serve a decorative and functional purpose. At the time, there was ample open space at this south east corner of the Marquette campus, and additional outdoor sculpture was installed, presumably, to beautify the area, draw people to the underutilized section of campus, and extend the museum's presence beyond its walls. As Senie suggested in her chapter 'Reframing Public Art: Audience Use, Interpretation, and Appreciation' the context would have an affect on the perception of the installation.The architects of Breaking Ground exploited the existing pedestrian traffic patterns that cut through the gridded trees of the sculpture garden to emphasize the spatial difference between the temporary installation and the existing buildings. In From Margin to Center: The Spaces of Installation Art author Julie Reiss foregrounds experience as part of installation art in the following manner: "there is always a reciprocal relationship of some kind between the reviewer and the work, the work and the space, and the space and the viewer." ${ }^{29}$ Approaching the installation, the body moved dynamically against the rigidity of the rectilinear forms of the adjacent buildings and the dominant tree grid.

The design and construction of Keith Haring's fence and mural served as both material and experiential reference points for Breaking Ground. Polycarbonate sheets, a translucent/transparent material typically deployed in industrial or commercial construction or as a replacement for glass, occupy a similar role as the standard plywood panels Haring transformed into his canvas. In the installation, two overlapping polycarbonate sheet systems, one $8 \mathrm{~mm}$ and the other $20 \mathrm{~mm}$, shifted to reveal variations of opacity, reflection, and transparency against the human figure. Upon entering Breaking Ground, the body was seen in new positions relative to the existing ground - feet became transposed from the ground to eye level while heads disappeared into the tree canopy. This form of compartmentalization accentuated the installation's involvement as an active participant in the voyeurism of the human body. The rolling topography around the site provided for additional levels of viewing heights. The view at eye level from a significant cross campus pathway (below grade relative to the bottom of the ramp) accentuated both the forced perspective and the undulating movement of the panels juxtaposed against a user on the ramp.

Not only did the polycarbonate panels provide a new way of viewing the body, they also manipulated the relative position of the user to the piece itself. As reported above, Senie stated audiences had positive responses to art when they could interact with the piece. The inner polycarbonate panels towered over someone entering the space, establishing a datum at 9' above grade. As the ramp inclined to a height of $6^{\prime}$, the polycarbonate surface transformed into railings that provided a tactile means for the hand to participate. This hovering horizontal datum, limiting peripheral views, accentuated the incline of the ramp and framed the sky for the user. The outer layer of polycarbonate panels remained at full size extending the compression of the space as the inner panels slipped out of the way. The space defined by the inner layer of polycarbonate morphed into the exterior space of the pulpit. Thus the material that defines the space of movement became the space of repose. 


\section{IMPROVISATIONAL DANCE AND MUSIC PERFORMANCE}

In an effort to add to the informal programming on Breaking Ground, a collaboration to create formal programming between the museum, Breaking Ground and a choreographer was set in motion. Using Stephan Koplowitz's definition of site-specific dance, the performance event was "wholly inspired by [the] specific site and cannot be replicated anywhere else without losing its essence and core meaning. ${ }^{30}$ The Breaking Ground performance event began at a distance from the installation, with the audience facing it, allowing for the piece to be situated within the space of the sculpture garden and adjacent to the museum. Dancers careened, leaped, and rolled down the tumbling terrain of small hills leading from other parts of campus into the sculpture garden, passing through the audience and inviting them to follow the dancers to the next performance vantage point.

On approach of the installation, the musicians - who had been playing an unheard sound score for the first section of the dance - became a part of the sensorial experience of the audience and the dancers. Highlighting both the slanting shape of the upward moving ramp and the transparency of the lower portion of the polycarbonate, one dancer lay down on the inner walkway and interacted with two dancers on either side of the piece. From there, the dancers moved to "the pulpit" and the audience shifted to the extreme opposite side of the sculpture, watching the action from below and activating the shifting power hierarchies set up by Breaking Ground.

Finally, reversing the notion of audience and stage, dancers and audience switched places with groups of 12-15 audience members entering the installation to experience the dancers fists pounding and shaking the installation from below to then viewing them activate slate tables and seats in the sculpture garden visible from the installation's highest vantage point. To end the performance, the audience reversed their orientation, looking back through the space of the installation, to watch the dancers retreat from where they came, but at the extreme opposite distance and with the kinesthetic experience of being enclosed within the installation's belly. This activated the entry threshold - the tilted panels that compressed the user upon entrance- as a viewing frame and engaged the audience in a similar fashion to the retreated performers.

The dance performance event attempted to create an environment where audience/patrons would experience the installation in the ways intended by the architects. Using the performers as focal points, the audience was led from one experience of the installation to another "to look at, listen to, feel, and think about the space in which the dance is performed. It also ask[ed] audiences to forgo the safety of the fourth wall and be active participants in the performance experience." ${ }^{\prime 31}$ Through the use of sound, movement, and shifting point of view, the performance created a "kinesthetic experience of place...engaging the senses in a sensory experience of place and exploring the different feeling states of place." $^{32}$

\section{CONCLUSIONS}

The various activities surrounding the Breaking Ground installation represent what Rachel and Alice Sara refer to as "trans-ontology, which implies not only a way of thinking that is across...domains, but also implies an altered way of being." ${ }^{\prime 3}$ Architecture, museum, and performance came together in discussion and collaboration, which had impacts on each of the domains and the pieces that they produced. The exploration revealed commonalities amongst the collaborators and their work including ephemerality of both the temporary installation and live dance/music performance and a focus on experience over utility.The installation Breaking Ground did not serve the same practical functions as a conventional building and the dance/music experience could not exist without the installation in the way a conventional dance piece can, all of which defined and redefined the space of the program, including the performance and day to day users of the pulpit, and demonstrated a commitment to making art and experiences accessible to the public .

The strength of the collaboration was in its ability to find opportunities to engage. These engagements created a civic space, for the gathering of creators, facilitators, and spectators for shared experience and meaningful creation. Quoting political theorist Benjamin Barber, Ann Daly calls "[c]ivic space...the mediating third sector that fuels strong democracy, because it is where 'democratic attitudes are cultivated and democratic behavior is conditioned'." ${ }^{34}$ It is within this civic space where "spatial systems can catalyze and mediate, among other cultural forces, social justice and ethical awareness and behavior." ${ }^{\prime 35}$

Out of the Breaking Ground experiences, additional ideas were born. One called for the activation of the $4 \times 8$ polycarbonate panels as a billboard in a similar way to the original Haring construction fence. The scale and positioning of Breaking Ground was such that the panels, when viewed broadside from a perpendicular angle to a major cross campus axis emphasized the 28' long flat surface like a giant billboard. Graffiti art offered a method of engaging youth in claiming ownership over a piece of art sitting in a seemingly public space on the campus of a private institution. Although this part of the project was not completed, the nature of the installation being a canvas with which to engage various art forms remained consistent.

The museum, the installation and the dance were all participatory figures that expanded upon ways to activate public space through new experiences. Much like the dance piece itself, Breaking Ground acted as protagonist and participant 
in shaping the public experience of this urban museum. Each of the experiences inverted traditional forms of civic and cultural engagement. The museum experience extended beyond its traditional walls into a public space. The dance and music performance transposed, through the use of the installation, audience and performer locations and traditions such that the engagement of the audience viewing the dance performance was also significant to watch.

\section{ENDNOTES}

1 Bernard Tschumi, The Manhattan Transcripts: Theatrical Projects (New York, NY: Academy Editions/St. Martin's, 1981).

2 Sarah Bonnemaison \& Ronit Eisenbach, Installations by Architects: Experiments in Building and Design (New York, NY: Princeton Architectural Press, 2009).

3 Ibid, 14.

4 Ibid, 14.

5 Rachel Sara \& Alice Sara, "Between Dance and Architecture" in Hunter, V. (Ed.), Moving Sites: Investigating Site-Specific Dance Performance (Abingdon, Oxon; New York: Routledge, 2015), 62.

6 Ibid, 77.

7 Andrew McClellan, "A Brief History of the Art Museum Public" in McClellan, A. (Ed.), Art and Its Publics: Museum Studies at the Millennium (Malden, MA: Blackwell Publishers, 2003) 2.

8 Ibid, 2.

9 Ibid, 17

10 Ibid, 28.

11 Ibid, 24.

12 Ibid, 29.

13 Ibid, 31.

14 Harriet F. Senie, "Reframing Public Art: Audience Use, Interpretation, and Appreciation" in McClellan, A. (Ed.), Art and Its Publics: Museum Studies at the Millennium (Malden, MA: Blackwell Publishers, 2003), 186.

15 Ibid, 186-187.

16 Ibid, 187

17 Ibid, 188

18 Ibid, 190

19 Ibid, $188-190$

20 Ibid, 194.

21 Robert Turner, Steve Paxton's "Interior Techniques": Contact Improvisation and Political Power. TDR: The Drama Review, Vol. 54, No. 3, (Fall 2010, T 207): 125.

22 Ann Daly, "Dancing Democracy," in Dance Research Journal, Vol. 34, No. 2 (Winter 2002), 10

23 Erinn Kelley Thompson Ernst, A Collaborative, Site-Specific Dance Performance for Alton Baker Park in Eugene, Oregon: Focus on Community Building For Participating Artists Through the Concepts of Space and Time. MFA Thesis, University of Oregon. ProQuest. Web. September 29, 2016.

24 Turner, 125.

25 Sally Banes, "Democracy's Body: Judson Dance Theatre and its Legacy." Performing Arts Journal, Vol. 5, No. 2, American Theatre: Fission/Fusion (1981) 103.

26 Faith Morrison, Creating and Conveying a Kinesthetic Experience of Place. MFA Thesis, University of Oregon. ProQuest. Web. September 29, 2016., 2.

27 Daly, 9.

28 Curtis Carter, "Revisiting the Keith Haring Mural at Marquette University" from On the Fence: Keith Haring's Mural for the Haggerty, 1983 (Milwaukee: Haggerty Museum of Art, 2005), 10.

29 Julie Reiss, From Margin to Center: The Spaces of Installation Art (Cambridge, MA: MIT Press, 1999) xiii.

30 Stephan Koplowitz, in Kloetzel, M. \& Pavlik, C.(Eds.), Site Dance: Choreographers and the Lure of Alternate Spaces (Gainesville: University Press of Florida, 2011): 75

31 Arianne MacBean, "Site Specific Dance: Promoting Social Awareness in Choreography." Journal of Dance Education, Vol. 4(3), 2004, 97.
32 Morrison, iv

33 Sarah \& Sara, 77

34 Daly, 8.

35 From the ACSA Session Call. 